\title{
Diversity of dinoflagellate symbionts (zooxanthellae) in a host individual
}

\author{
Alvin A. Carlos ${ }^{1}$, Brett K. Baillie ${ }^{2}$, Tadashi Maruyama ${ }^{2, *}$ \\ 'Marine Science Institute, College of Science, University of the Philippines, Diliman, Quezon City 1101, Philippines \\ ${ }^{2}$ Marine Biotechnology Institute, Kamaishi Laboratories, Heita 3-75-1, Kamaishi, Iwate 026-0001, Japan
}

\begin{abstract}
Zooxanthellae are phototrophic dinoflagellates that exist in symbiosis with a variety of marine invertebrates. The traditional view of zooxanthella-invertebrate symbioses suggests that individual hosts harbor taxonomically homogeneous symbiont populations. To assess the diversity of the zooxanthella assemblage inhabiting an individual host, zooxanthellae from 6 species of clam (Tridacna gigas, T. squamosa, T crocea, Hippopus hippopus, H. porcellanus and Corculum cardissa) and 1 species of sea anemone (Aiptasia sp.) were studied using temperature-gradient gel electrophoresis (TGGE), coupled with polymerase chain reaction (PCR) using zooxanthella-specific primers that were designed to target hypervariable regions of the small subunit ribosomal RNA (ssrRNA) gene. Results revealed that 1 clam may harbor 2 or more genotypically distinct zooxanthellae, with 1 or more dominant taxa occurring at a time. The clams studied associated with at least 4 zooxanthellar taxa. Nucleotide sequencing af the TGGE bands and phylogenetic reconstruction revealed that the zooxanthellar taxa in clams were Symbiodinium spp.; 1 was identical to previously cultured clam symbiont isolates, 1 appeared identical to a previously studied unculturable clam symbiont, and the other 2 clams represented novel strains of Symbiodinium. Individual Aiptasia sp. harbored only 1 zooxanthellar taxon, which had a ssrRNA sequence identical to that of $S$. pulchrorum, previously isolated from Aiptasia pulchella. This study has shown that individual tridacnid and cardiid clams can harbor heterogeneous zooxanthellae.
\end{abstract}

KEY WORDS: Zooxanthellae - Diversity - Temperature-gradient gel electrophoresis - Dinoflagellates · Clams

\section{INTRODUCTION}

Zooxanthellae are symbiotic dinoflagellates that form mutual associations with a wide range of marine invertebrates (Taylor 1974, Trench 1987). They supply energy to their host in the form of fixed carbon compounds (Muscatine et al. 1984, Klump et al. 1992), and are essential to the host's growth and survival under nutrient-limited conditions (Bé et al. 1982). The acquisition of these dinoflagellate symbionts is considered to have played a key role in the ecological success of reef-building corals since their appearance in the Triassic Period (Heckel 1974).

The traditional view of zooxanthella-invertebrate symbioses holds that 1 host species harbors phenotyp-

\footnotetext{
- Corresponding author.

E-mail: tadashi.maruyama@kamaishi.mbio.co.jp
}

ically and genotypically homogeneous algal populations (Schoenberg \& Trench 1980, Rowan \& Powers 1991a,b, Stochaj \& Grossman 1997). Recent molecular techniques have circumvented limitations posed by the need to bring the symbionts into culture, and have consequently advanced our knowledge of symbiont diversity (for review, see Rowan 1998). Restriction fragment length polymorphism (RFLP) analysis, in combination with PCR (polymerase chain reaction) amplification of genes encoding the small and large subunit ribosomal RNA (ssrRNA and lsrRNA, respectively), has shown that the Caribbean corals Montastraea annularis and $M$. faveolata can each associate with 3 distinct taxa of zooxanthellae, either 1 or 2 at a time (Rowan \& Knowlton 1995). These findings have contributed to a better understanding of host distribution, ecology, and response to environmental changes (Rowan et al. 1997). While RFLPs reveal the genetic 
diversity of disparate and dominant symbionts within a host, it is difficult to resolve closely related taxa and to show the presence of minor symbionts (Rowan \& Knowlton 1995).

To assess the genetic diversity of zooxanthellae harbored in an individual host, we employed temperature-gradient gel electrophoresis (TGGE; Rosenbaum \& Riesner 1987), an analog of denaturing gradient gel electrophoresis (DGGE; Fischer \& Lerman 1979) that has been used in the analyses of genetic diversities of complex bacterial populations (Muyzer et al. 1993), and of eukaryotes in aquatic environments (Van Hannen et al. 1998). By PCR gene amplification using a primer with a GC-rich sequence at its 5' end (Sheffield et al. 1989), these techniques resolve almost all of the possible sequence variation. In addition, these techniques are used to estimate densities of uncultured bacterial populations (Watanabe \& Harayama 1998). Using PCR with zooxanthella-specific primers and TGGE, we analyzed the genetic diversity of the zooxanthellar communities in tridacnid and cardiid clams, and showed that 2 or more symbiont taxa can reside in an individual clam. The presence of different zooxanthellar taxa, which had been previously indistinguishable by RFLP, is revealed. The implications of this zooxanthellar genetic diversity among host species and within a single host individual are discussed.

\section{METHODS AND MATERIALS}

Zooxanthella isolation. Zooxanthellate bivalves Tridacna crocea, T. gigas, Hippopus hippopus, H. porcellanus, and Corculum cardissa were collected from their natural habitat in Palau or purchased from the Palauan Mariculture Demonstration Center (PMDC; Palau). A giant clam, T. squamosa, was purchased from Onna-son fisheries union (Okinawa, Japan). Aiptasia sp. was collected from Okinawa prefecture, Japan, and maintained in an aquarium at $25^{\circ} \mathrm{C}$.

Zooxanthellae residing in Aiptasia sp. and in the mantle tissue of zooxanthellate bivalves were isolated as follows: host tissues were washed repeatedly with filtered $(0.45 \mu \mathrm{m})$ natural seawater, homogenized with a polytron-type homogenizer (Ystral, Germany), filtered through a $30 \mu \mathrm{m}$ nylon mesh, the filtrate centrifuged at $500 \times g$ for $3 \mathrm{~min}$, and the sedimented zooxanthellae washed repeatedly with filtered seawater.

To study the change of diversity during cultivation of zooxanthellae in a culture medium, the isolated algal cells in the Tridacna squamosa specimen were inoculated in K medium (Keller et al. 1987) and grown under a cool-white fluorescent lamp with a 14:10 h light:dark cycle at 22 to $25^{\circ} \mathrm{C}$. DNA extracts were obtained before and after cultivation.
DNA extraction and gene amplification. Zooxanthellar pellets were suspended in TE-SDS extraction buffer (10 mM Tris; $100 \mathrm{mM}$ EDTA, pH 8.0; $0.05 \%$ $\mathrm{SDS}$ ). An aliquot was transferred to a $2 \mathrm{ml}$ tube containing $1 \mathrm{ml}$ of $800 \mu \mathrm{m}$ glass beads. The zooxanthellar cell walls were then disrupted in a mini-beadbeater (Model 3110BX, Biospec Products, Bartlesville, OK, USA) at $5000 \mathrm{rpm}$ for $5 \mathrm{~min}$. Zooxanthellar lysates were examined under a microscope to confirm the rupture of the algal cell walls. The lysate was incubated at $50^{\circ} \mathrm{C}$ for $3 \mathrm{~h}$ in the presence of Proteinase $\mathrm{K}\left(0.1 \mathrm{mg} \mathrm{ml}^{-1}\right)$, followed by incubation at $37^{\circ} \mathrm{C}$ for $1 \mathrm{~h}$ in the presence of RNase A (DNase-free, $10 \mu \mathrm{g} \mathrm{ml}^{-1}$ ). Samples were extracted once with an equal volume of phenol, and twice with equal volumes of chloroform. DNA was precipitated by addition of 0.02 volume of $5 \mathrm{M} \mathrm{NaCl}$ and 2.5 volume of cold $99.5 \%$ ethanol, followed by incubation at $-80^{\circ} \mathrm{C}$ for $30 \mathrm{~min}$, and centrifugation at $10000 \times g$ for $10 \mathrm{~min}$. The DNA pellets were then washed with cold $70 \%$ ethanol, dried in a vacuum centrifuge for $10 \mathrm{~min}$, and dissolved in $50 \mu \mathrm{l}$ TE buffer (10 mM Tris; $1 \mathrm{mM}$ EDTA, pH 8.0). DNA was quantified by measuring the absorbance at $260 \mathrm{~nm}$ using a DU 640 spectrophotometer (Beckman Instruments, Inc., Fullerton, CA, USA).

The ssrRNA gene sequences of 4 zooxanthellar species (Symbiodinium microadriaticum, S. pulchrorum, Gymnodinium beii, and Gleodinium viscum), 4 invertebrate species (sponge Clathrina cerebrum, coral Tubastrea aurea, sea anemone Anthopleura kurogane, and giant clam Tridacna gigas) were aligned. After alignment, a primer set flanking the variable regions $\mathrm{V} 1$ and $\mathrm{V} 2$ of the ssrRNA gene (Dams et al. 1988), which would specifically amplify that of zooxanthellae but not of the hosts, was designed (Fig. 1). A 40 bp $\mathrm{G}+\mathrm{C}$-rich sequence, the GC-clamp (Sheffield et al. 1989), was attached to the 5 ' end of the reverse primer. The sequences of the primer set are as follows: $z 8$ (forward) 5'-GTCTCAAAGATTAAGCCATG-3'; zPV2R (reverse) 5'-GCCCGCCGCGCGCGGCGGGCGGGGCGGGGGCACGGGGGGCTCCGTTACCCGTCATT-

GCC-3' (annealing region underlined). The targeted $\overline{D N A}$ region was amplified using the AmpliTaq Gold kit (PE Applied Biosystems, Foster City, CA, USA) and the TP 240 PCR Thermal Cycler PERSONAL (Takara Biomedicals, Japan) under the following conditions: $94^{\circ} \mathrm{C}$ for $12 \mathrm{~min} ; 30$ cycles of $94^{\circ} \mathrm{C}$ for $30 \mathrm{~s}, 50^{\circ} \mathrm{C}$ for $30 \mathrm{~s}, 68^{\circ} \mathrm{C}$ for $2 \mathrm{~min}$. PCR products were run on $1.5 \%$ agarose gel to check the size (about $370 \mathrm{bp}$ ) of the band.

Clonal cultures of the Symbiodinium isolates PLTM1, HA 3-5 and PSP1-05 were included in the analysis to check the extent of polymorphism within the multicopy ssrRNA genes. These clonal isolates were obtained respectively, from the giant clam Tridacna max- 


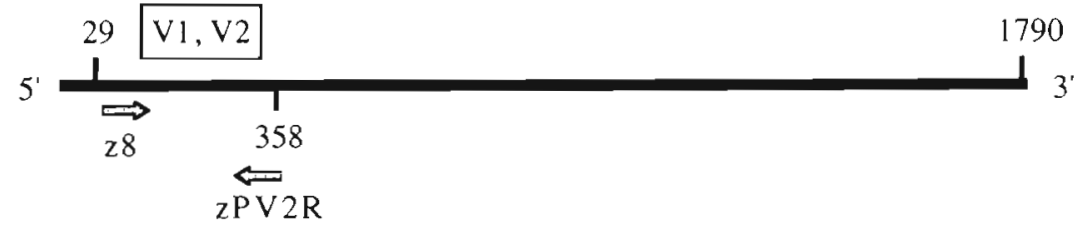

29

Fig. 1. Design of zooxanthellaspecific primer set $(z 8$ and zPV2R) flanking the V1 and V2 regions of the ssrRNA gene. Portions of the ssrRNA gene sequence of the zooxanthellae Symbiodinium microadriaticum (ZX1), S. pulchrorum (ZX2), Gymnodinium beii (ZX3), Gleodinium viscum (ZX4), and the sponge Clathrina cerebrum (H1), the coral Tubastrea aurea (H2), the sea anemone Anthopleura kurogane ( $\mathrm{H} 3)$, and the giant clam Tridacna gigas (H4), are shown in the alignment. The primer set amplifies the ssrRNA gene region of all zooxanthellae and not of the invertebrates, as the reverse primer (2PV2R) does not anneal to the invertebrate ssrRNA genes $(\mathrm{z} \times 1)$

$(\mathrm{z} \times 2)$

$(2 \times 3)$

( $2 \times 4)$

(H1)

(H2)

( $\mathrm{H} 3$ )

(H4)

GGTTGATCCTGCCAGTAGTCATATGCTTGTCTCAAAGATTAAGCCATGCATGTCTCAGTATAAGC

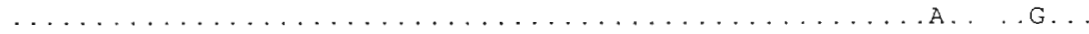

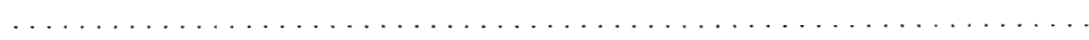

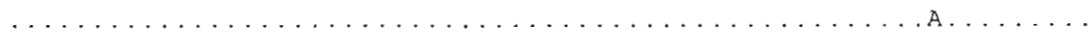

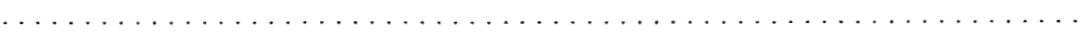

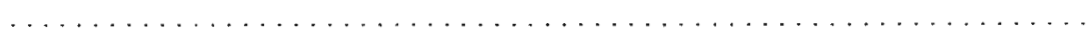

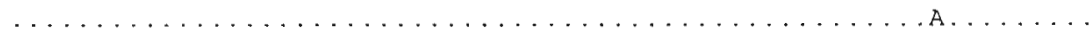

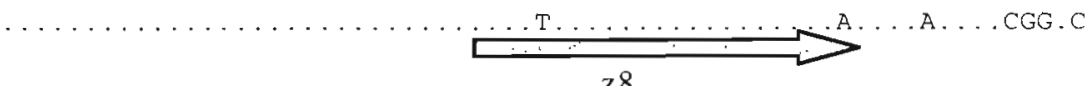

$\mathrm{z} 8$

358

$(\mathrm{z} \times 1)$

$(2 \times 2)$

$(2 \times 3)$

(2X4)

(H1)

(H2)

(H3)

(H4)
CTACCGTGGCAATGACGGGTAACGGAGAATTAGGGTTTGATTCCGGAGAGGGAGCCTGAG

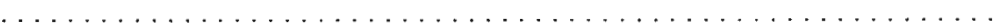



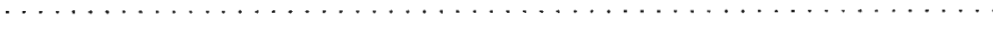

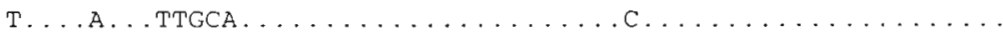

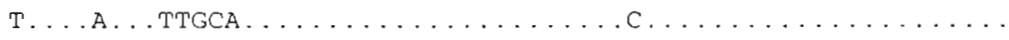

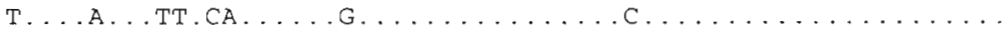

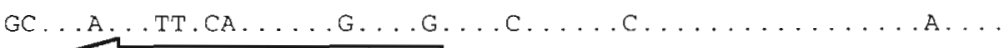

$z P \vee 2 R$ ima, from intertidal sands in Hawaii, and from the sponge Haliclona koremella. Their ssrRNA gene sequences, whose accession numbers in DDBJ (DNA data base of Japan) are AB016576, AB016572 and $A B 016578$, respectively, have been shown to be different (Carlos et al. 1999).

Temperature-gradient gel electrophoresis (TGGE). Aliquots $(5 \mu l)$ of the PCR products were electrophoresed in gels containing $8 \%$ acrylamide, $3 \mathrm{M}$ urea and $20 \%$ (v/v) formamide with half-strength TBE buffer (Maniatis et al. 1982) using a TG-180 TGGE apparatus (Taitec Corp., Japan) under a linear temperature gradient of 36 to $52^{\circ} \mathrm{C}$. After electrophoresis at $250 \mathrm{~V}$ at $13 \mathrm{~mA}$ for $3.5 \mathrm{~h}$, the gel was stained in ethidium bromide for 20 min and viewed under a UV illuminator. Bands were excised and incubated with shaking in a tube containing $100 \mu \mathrm{l}$ of TE buffer at $30^{\circ} \mathrm{C}$ for $24 \mathrm{~h}$. The eluted DNA was precipitated using $99.5 \%$ ethanol, washed with $70 \%$ ethanol, dried in a vacuum centrifuge, and dissolved in $20 \mu \mathrm{l}$ of TE buffer.

Re-amplification and sequencing of the TGGE band. The purified DNA fragments from TGGE were re-amplified using the same primers and PCR conditions. Repeating the TGGE procedure under the same conditions confirmed the purity of the re-amplified products. Nucleotide sequences of the amplified products were determined using the ABI PRISM Dye Terminator Cycle Sequencing Ready Reaction Kit (PE
Applied Biosystems, Foster City, CA, USA) and nested sequencing primers ( $\mathrm{z} 9$ [forward]: 5'-ATGCATGTCTCAGTATAAGC-3'; zSV2R [reverse]: 5' - CTCCGTTACCCGTCATTGCC-3'). Sequences were read on a 377 DNA Sequencer (PE Applied Biosystems, Foster City, CA, USA).

Three previously unreported zooxanthellar ssrRNA gene sequences were submitted to DDBJ (DNA database of Japan). Their accession numbers are AB024982, AB016797 and AB016813, corresponding to TsZx2 (genotype 3) from Tridacna squamosa, HhZx1 (genotype 1) from Hippopus hippopus and Cczx1 (genotype 3) from Corculum cardissa, respectively.

Identification of the zooxanthellar taxa. The identities of the zooxanthellar taxa, based on nucleotide sequences of TGGE bands, were determined following sequence alignment and phylogenetic reconstruction. The ssrRNA gene sequences were aligned using the multiple sequence alignment program ClustalW version 1.7 (Thompson et al. 1994). Sequences of reported Symbiodinium species available in the Genbank database were included in the alignment. Ambiguous regions represented by gaps/insertions and the flanking primer regions were excluded from the analysis. The ssrRNA gene sequences consisted of 271 aligned sites. Phylogenetic reconstruction, using the neighborjoining distance method (Saitou \& Nei 1987), was done with ClustalW version 1.7 using a Kimura 2 parameter 
distance matrix. Reliabilities of the clades were estimated by bootstrap re-sampling of the aligned data set 1000 times.

\section{RESULTS}

Prior to the analysis of zooxanthellar communities in the host animals, we investigated whether a zooxanthellar clone has multiple distinct copies of the ssrRNA gene. The TGGE analysis of the 3 distinct clonal zooxanthellar strains each revealed a single band, which differed in mobility among the clones (Fig. 2). This indicated that differences among the ssrRNA gene copies in these zooxanthellar clones are negligible, and that TGGE analysis is able to resolve differences in ssrRNA gene sequences. In this case, each band in the TGGE thus represents a single zooxanthellar genotype.

More than 2 genotypically distinct zooxanthellae were detected in each of the clam individuals (Fig. 3A). Two or more genotypically distinct, equally abundant, zooxanthellae were observed in Corculum cardissa, Hippopus hippopus, and Tridacna squamosa (Fig. 3A, lanes 3,4 and 6 , respectively). Only 1 major zooxanthella was observed in $T$. gigas, $H$. porcellanus, and $T$. crocea (Fig. 3A, lanes 1, 2 and 5, respectively).

Four major zooxanthellar genotypes in the bivalve specimen were named genotypes 1 to 4 (Fig. 3A) and further analyzed by reamplification of DNA in the bands. TGGE-genotype 1 was found only in the Hippo-

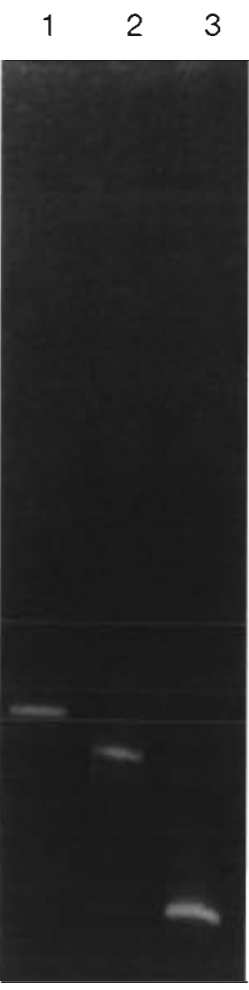

Fig. 2. TGGE profile of clonal cultures of zooxanthellae, showing the absence of significant polymorphism among the multi-copies of the ssrRNA gene. Lane 1: Symbiodinium sp. PLTM-1 isolated from the giant clam Tridacna maxima; lane 2: Symbiodinium sp. HA3-5 collected from sands in Hawaii i lane 3: Symbiodinium sp. PSP1-05 isolated from the sponge Haliclona koremella pus hippopus specimen. Genotype 2 was present in $T$. crocea and Tridacna squamosa. Genotype 3 was a major symbiont in both Corculum cardissa and $T$ squamosa. Genotype 4 was a major symbiont in most bivalve hosts, except $T$ crocea and $T$. squamosa, where it was only a minor taxon.

Only 1 zooxanthellar genotype (sea anemone zx1) was observed in individuals of Aiptasia sp. (Fig. 3B).
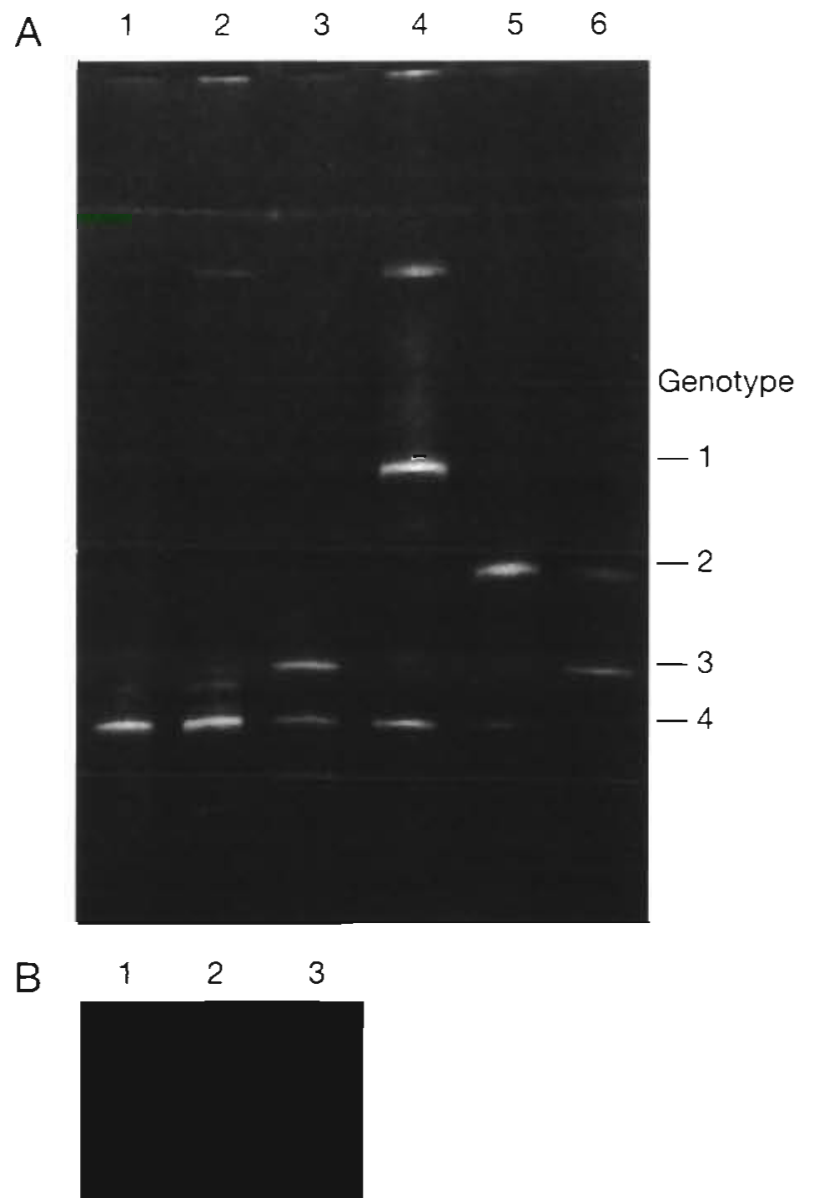

Fig. 3. Zooxanthellar diversity in host individuals as revealed using TGGE analysis. One band corresponds to 1 genotype, and its relative intensity indicates relative abundance of that population in the host individual. (A) Zooxanthellae in individual Tridacna gigas (lane 1); Hippopus porcellanus (lane 2); Corculum cardissa (lane 3); H. hippopus (lane 4); $T$. crocea (lane 5); T. squamosa (lane 6). (B) Zooxanthellar diversity in 3 specimens of Aiptasia $\mathrm{sp}$. (lanes 1 to 3 ) 
Fig. 4. Neighbor-joining comparison of the different zooxanthellae taxa in each of the host individuals with respect to representative Symbiodinium taxa. Hosts: Ts, Tridacna squamosa; Tc, $T$ crocea; Cc, Corculum cardissa; Hp, Hippopus porcellanus; $\mathrm{Tg}, T$. gigas; $\mathrm{Hh}, H$. hippopus; $\mathrm{zx} 1$ and $\mathrm{zx}$ : the $n$th major zooxanthellae population in each host individual. Only $>50 \%$ bootstrap values are shown. ${ }^{*}$ Culturable zooxanthellae strains isolated from tridacnid and cardiid bivalves. **Zooxanthellae strains unculturable in our culture conditions and were detected only by their DNA

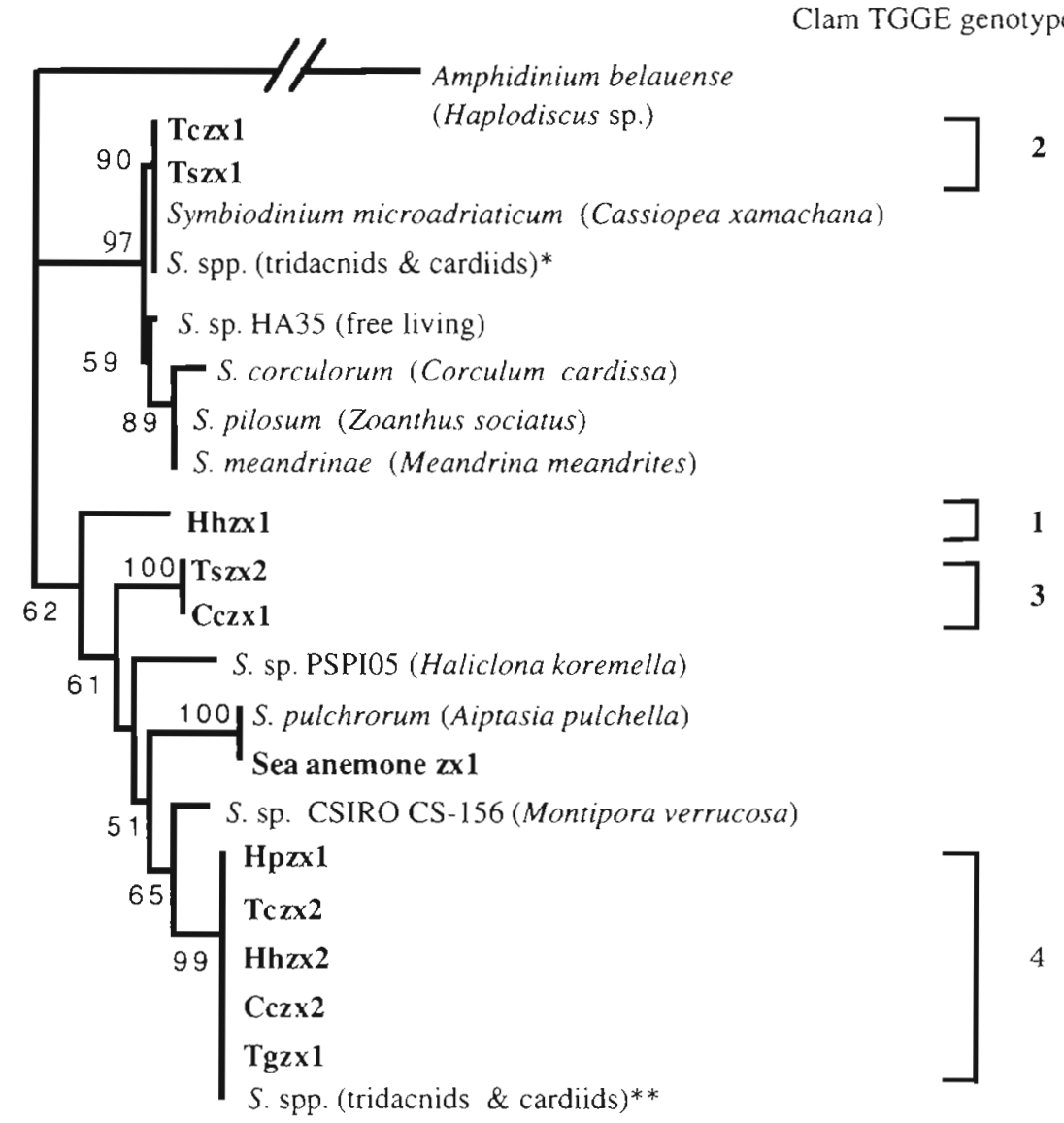

0.1
Fig. 5. Diversity within freshly isolated zooxanthellae in a specimen of Tridacna squamosa (lane 1) and within zooxanthellae cultured from this clam (lane 2)
Although the sequences obtained were too short for a complete phylogenetic analysis, phylogenetic reconstruction (Fig. 4) revealed that genotype 2, observed in Tridacna crocea and $T$. squamosa, was identical to other Symbiodinium spp. isolated from clams (Carlos et al. 1999). Genotype 4, which was equally dominant in almost all the clams studied except in $T$. squamosa and $T$. croced, was identical to the Symbiodinium strains whose sequences were previously abtained via gene cloning of the amplified DNA fragment (Carlos et al. 1999). Genotypes 1 and 3 are clearly distinct from the rest of the Symbiodinium taxa, and thus represent novel zooxanthellar strains. The sole zooxanthellar taxon residing in the Aiptasia sp. specimens was identical to $S$, pulchrorum isolated from a similar host.

The profile of zoxanthellae freshly isolated from the Tridacna squamosa specimen (Fig. 5, lane 1) differed from that of the same isolate of zooxanthellae after culture (Fig. 5, lane 2). The symbiont, represented by genotype 2 (upper band), dominated in culture, indicating that either only this genotype is culturable, or it was able to successfully compete against the geno- 
type-3 symbiont (lower band) under the culture conditions employed.

\section{DISCUSSION}

Our study revealed that individual giant and cardiid clams can harbor a distinct or heterogeneous assemblage of zooxanthellae, and that clam species studied can associate with at least 3 zooxanthellar taxa (TGGE genotypes 2, 3 and 4). Similar diversity in zooxanthellae communities has been reported by Rowan et al. (1997), who showed that up to 3 taxa of zooxanthellae can inhabit a single coral host. Previously, Rowan \& Knowlton (1995) revealed that colonies of the Caribbean stony corals Montastraed annularis and $M$. faveolata associated with 4 distinct zooxanthellar RFLP genotypes, either 1 or 2 at a time, thus confirming the long-standing speculation that a population of conspecific hosts may associate with several distinct zooxanthellae. Similar observations were subsequently made on colonies of Caribbean scleractinians Acropora cervicornis (Baker et al. 1997), Porites astreoides, Stephanocoenia michelinii. Diploria labyrinthiformis (Baker \& Rowan 1997), Montastraea Cavernosa and Diploria strigosa (Wilcox 1996), and on the giant clam Tridacna gigas (Rowan et al. 1996).

In addition, TGGE detected distinct zooxanthellar taxa with higher resolution than RFLP. PCR-TGGE analysis coupled with nucleotide sequencing has revealed both unculturable and minor zooxanthellae within host individuals. Despite the fact that there could be more than 1 distinct copy of ssrRNA genes in 1 organism (Scholin et al. 1993), no significant ssrRNA gene copy polymorphism was observed (for example see Fig. 2).

Previously we cultured zooxanthellae from tridacnid and cardiid bivalves and found that their ssrRNA gene sequences were identical (Carlos et al. 1999), implying that this symbiont genotype (TGGE genotype 2; Fig. 4) was the dominant taxon in the clams. However, our TGGE analysis detected this zooxanthellar genotype only in the Tridacna crocea and $T$. squamosa. This suggests that zooxanthellar genotype 2 was present in the clams but in undetectable amounts, and that its isolation was favored over the 3 other, numerically dominant, genotypes under our culture conditions. This hypothesis is supported by the difference between the TGGE profiles of freshly isolated and cultured zooxanthellae. Under the culture conditions we used, only the genotype 2 symbiont grew (Fig. 5).

We previously sequenced the ssrRNA gene of zooxanthellae from 3 species of clams (Tridacna gigas, Fragum unedo and $F$. fragum) via gene cloning, and found that they are distinct from that of the cultured isolates (Carlos et al. 1999), and correspond to TGGE genotype 4 . The TGGE analysis revealed that this symbiont genotype was actually present in the majority of the clam specimens studied.

The advantages that a host gains from its association with different zooxanthellar genotypes may depend on the extent of variation among different symbiont taxa. Differences in photoadaptation (Iglesias-Prieto \& Trench 1994) and physiological response to UV radiation (Banaszak \& Trench 1995) have been observed among different zooxanthellar taxa, and thus may indicate an assemblage of 'genotypically different-physiologically different' taxa of symbionts. The observation that zooxanthellar genotypes follow zonation by depth in colonies of polymorphic Caribbean corals (Rowan \& Knowlton 1995, Baker et al. 1997) would support the hypothesis that the ability to associate with different types of zooxanthellae permits hosts to adapt to different photic habitats (Trench 1988). Hosts that have a wider range of symbiont 'tolerance' may have an adaptive advantage during periods of environmental perturbations, as has been suggested for coral bleaching (Rowan et al. 1997, see also Rowan 1998).

Our observation of host individuals harboring 2 genotypically distinct, equally abundant zooxanthellae at a given time challenges the ecological theory of competitive exclusion. What allows these 2 distinct symbionts to co-exist in the same niche? One possible explanation is suggested by Hutchinson's (1961) concept of diversity under non-equilibrium conditions (see also Douglas 1998). Two distinct algae occupying the same niche may co-exist when, in most instances before one outcompetes the other, changes in the environment result in a shift in the direction of competition in favor of the latter. The underlying assumption is that the time between environmental changes is shorter than the time required by one taxon to outcompete the other. A second explanation would be that the host individual, considered here as a habitat, is itself further divided into a variety of microhabitats that enable the different algae to sub-specialize into respective microniches, removing the need for the different symbiont taxa to compete and exclude each other. This may be especially true for hosts such as the giant clams, whose zooxanthellar tube system (Norton et al. 1993) may generate microhabitats for different symbionts. The verification of these hypotheses might pave the way for future studies on the population dynamics of zooxanthellae residing in a host. Some zooxanthellae in the free-living state may infect giant clams occasionally and may symbiose transiently (Douglas 1998). We have previously observed free living zooxanthellae in the sand of Hawaii (Carlos et al. 1999), and the distribution of free living zooxanthellae remains an important question for future studies. 
Acknowledgements. We thank Dr K. Watanabe for advice in TGGE, and Dr M. Kawachi for the unialgal cultures. Experimental work was carried out by A.A.C. in the Marine Biotechnology Institute, Japan, and he gratefully acknowledges the support of all its members. Financial support was provided by the Japan International Cooperation Agency (JICA) to A.A.C. This work was conducted as part of The Industrial Science and Technology Frontier Program supported by the New Energy and Industrial Technology Development Organization.

\section{LITERATURE CITED}

Baker AC, Rowan R (1997) Diversity of symbiotic dinoflagellates (zooxanthellae) in scleractinian corals of the Caribbean and Eastern Pacific. Proc 8th Int Coral Reef Symp 2:1301-1306

Baker AC, Rowan R, Knowlton N (1997) Symbiosis ecology of two Caribbean acroporid corals. Proc 8th Int Coral Reet Symp 2:1295-1300

Banaszak AT, Trench RK (1995) Effects of ultraviolet (UV) radiation on marine microalgal-invertebrate symbioses. I. Response of the algal symbionts in culture and in hospite. J Exp Mar Biol Ecol 194:213-232

Bé AWH, Spero HJ, Anderson OR (1982) Effects of symbiont elimination and reinfection on the life processes of the planktonic foraminifer Globigerinoides sacculifer. Mar Biol 70:73-86

Carlos AA, Baillie BK, Kawachi M, Maruyama T (1999) Phylogenetic position of Symbiodinium (dinophyceae) isolates from Tridacnids (Bivalvia), a sponge (Porifera), a soft coral (Anthozoa) and a free-living strain. J Phycol 35:1054-1062

Dams E, Hendriks L, Van de Peer Y, Neefs JM, Smits G, Vandenbempt I, De Wachter R (1988) Compilation of small ribosomal subunit RNA sequences. Nucleic Acids Res 16(Suppl):87-173

Douglas AE (1998) Host benefit and the evolution of specialization in symbiosis. Heredity 81:599-603

Fischer SG, Lerman LS (1979) Length-independent separation of DNA restriction fragments in two dimensional gel electrophoresis. Cell 16:191-200

Heckel PH (1974) Carbonate buildup in the geologic record: a review. In: Laporte LF (ed) Reefs in time and space. Spec Publs Soc Econ Palont Miner Tulsa, Oklahoma, p 90-154

Hutchinson GE (1961) The paradox of the plankton. Am Nat 95:137-145

Iglesias-Prieto R, Trench RK (1994) Acclimation and adaptation to irradiance in symbiotic dinoflagellates. I. Responses of the photosynthetic unit to changes in photon flux density. Mar Ecol Prog Ser 113:163-175

Keller MD, Selvin RC, Claus W, Guillard RRL (1987) Media for the culture of oceanic ultraphytoplankton. J Phycol 23: 633-638

Klump DW, Bayne BL, Hawkins AJS (1992) Nutrition of the giant clam Tridacna gigas (L.). I. Contributions of filter feeding and photosynthesis to respiration and growth. J Exp Mar Biol Ecol 155:105-122

Maniatis T, Fritsch EF, Sambrock J (1982) Molecular cloning; a laboratory manual. Cold Spring Harbor Laboratory, New York

Muscatine L, Falkowski PG, Porter JW, Dubinsky Z (1984) Fate of photosynthetically-fixed carbon in light and shadeadapted colonies of the symbiotic coral Stylophora pistillata. Proc R Soc Lond B 222:181-202

Muyzer G, De Waal EC, Uitterlinden AG (1993) Profiling of complex microbial populations by denaturing gradient gel electrophoresis analysis of polymerase chain reactionamplified genes coding for $16 \mathrm{~S}$ rRNA. Appl Environ Microbiol 59:695-700

Norton JH, Shepherd MA, Long HM (1993) The zooxanthellal tube system in the giant clam. In: Fitt WK (ed) Biology and mariculture of giant clams. Australian Centre for International Agricultural Research (ACIAR), Canberra, p 14-17

Rosenbaum V, Riesner D (1987) Temperature-gradient gel electrophoresis. Thermodynamic analysis of nucleic acids and proteins in purified form and in cellular extracts. Biophys Chem 26:235-246

Rowan R (1998) Diversity and ecology of zooxanthellae on coral reefs. J Phycol 34:407-471

Rowan R, Knowlton N (1995) Intraspecific diversity and ecological zonation in coral-algal symbiosis. Proc Natl Acad Sci USA 92:2850-2853

Rowan R, Powers DA (1991a) Molecular genetic identification of symbiotic dinoflagellates (zooxanthellae). Mar Ecol Prog Ser 71:65-73

Rowan R, Powers DA (1991b) A molecular genetic classsification of zooxanthellae and the evolution of animal-algal symbioses. Science 251:1348-1351

Rowan R, Whitney SM, Fowler A, Yellowlees D (1996) Rubisco in marine symbiotic dinoflagellates: form II enzymes in eukaryotic oxygenic phototrophs encoded by a nuclear multigene family. Plant Cell 8:539-553

Rowan R, Knowlton N, Baker A, Jara J (1997) Landscape ecology of algal symbionts creates variation in episodes of coral bleaching. Nature 388:265-269

Saitou N, Nei M (1987) The neighbor-joining method: a new method for reconstructing phylogenetic trees. Mol Biol Evol 4:406-425

Schoenberg DA, Trench RK (1980) Genetic variation in Symbiodinium (=Gymnodinium) microadriaticum Freudenthal, and specificity in its symbiosis with marine invertebrates. I. Isoenzyme and soluble protein patterns of axenic cultures of S. microadriaticum. Proc R Soc Lond B 207 : $405-427$

Scholin CA, Anderson DM, Sogin ML (1993) Two distinct small-subunit ribosomal RNA genes in the North American toxic dinoflagellate Alexandrium fundyense (Dinophyceae). J Phycol 29:209-216

Sheffield VC, Cox DR, Lerman LS, Myers RM (1989) Attachment of a 40-base-pair $\mathrm{G}+\mathrm{C}$-rich sequence ( $\mathrm{GC}$-clamp) to genomic DNA fragments by the polymerase chain reaction results in improved detection of single-base changes. Proc Natl Acad Sci USA 86:232-236

Stochaj WR, Grossman AR (1997) Differences in the protein profiles of cultured and endosymbiotic Symbiodinium $\mathrm{sp}$ (Pyrrophyta) from the anemone Aiptasia pallida (Anthozoa). J Phycol 33:44-53

Taylor DL (1974) Symbiotic marine algae: taxonomy and biological fitness. In: Vernberg WB (ed) Symbiosis in the sea. University of South Carolina Press, Columbia, p 245-262

Thompson JD, Higgins DG, Gibson TJ (1994) CLUSTAL. W: improving the sensitivity of progressive multiple sequence alignment through sequence weighting, positions-specific gap penalties and weight matrix choice. Nucleic Acids Res 22:4673-4680

Trench RK (1987) Dinoflagellates in non-parasitic symbioses. In: Taylor FJR (ed) The biology of dinoflagellates. Blackwell Scientific Publications, Oxford, p 530-570

Trench RK (1988) Specificity in dinomastigote-marine invertebrate symbioses: an evaluation of hypotheses of mechanisms involved in producing specificity. In: Scannerini S, Smith DC, Bonfante P, Giananazzi-Pearson V (eds) Cell to 
cell signals in plant, animal and microbial symbiosis. Springer-Verlag, Berlin, p 325-346

Van Hannen EJ, van Agterveld MP, Gons, HJ, Laanbroek HJ (1998) Revealing genetic diversity of eukaryotic microorganisms in aquatic environments by denaturing gradient gel electrophoresis. J Phycol 34:206-213

Editorial responsibility: Otto Kinne (Editor), Oldendorf/Luhe, Germany
Watanabe K, Harayama S (1998) Rapid estimation of population densities of uncultured bacteria in the environment. Microb Environ 13:123-127

Wilcox T (1996) Relationship among algal symbiont diversity, specificity, and symbiont transmission in Caribbean reef corals. Proc 8th Int Coral Reef Symp 2:209 (abstract)

Submitted: April 16, 1999; Accepted: September 15, 1999 Proofs received from author(s): March 13, 2000 